\title{
Tick-borne pathogens and the vector potential of ticks in China
}

\author{
Zhijun Yu, Hui Wang, Tianhong Wang, Wenying Sun, Xiaolong Yang and Jingze Liu*
}

\begin{abstract}
Ticks, as obligate blood-sucking ectoparasites, attack a broad range of vertebrates and transmit a great diversity of pathogenic microorganisms. They are considered second only to mosquitoes as vectors of human disease, and the most important vector of pathogens of domestic and wild animals. Of the 117 described species in the Chinese tick fauna, 60 are known to transmit one or more diseases: 36 species isolated within China and 24 species isolated outside China. Moreover, 38 of these species carry multiple pathogens, indicating the potentially vast role of these vectors in transmitting pathogens. Spotted fever is the most common tick-borne disease, and is carried by at least 27 tick species, with Lyme disease and human granulocytic anaplasmosis ranked as the second and third most widespread tick-borne diseases, carried by 13 and 10 species, respectively. Such knowledge provides us with clues for the identification of tick-associated pathogens and suggests ideas for the control of tick-borne diseases in China. However, the numbers of tick-associated pathogens and tick-borne diseases in China are probably underestimated because of the complex distribution and great diversity of tick species in this country.
\end{abstract}

Keywords: Ticks, Tick-borne pathogens, Vector potential, China

\section{Review}

Ticks, as obligate blood-sucking ectoparasites, attack a broad range of vertebrates, including humans, and they are considered second only to mosquitoes as vectors of human disease, and the most important vector of pathogens of domestic and wild animals [1]. They transmit a variety of pathogens of medical and veterinary interest, including viruses, bacteria, rickettsiae, helminthes, and protozoans, all of which are able to cause damage to livestock production and human health. The global threat of tick-borne diseases is increasing, with new pathogens identified continuously [2]. There are an estimated 899 species of ticks belonging to three families: Argasidae, Ixodidae, and Nuttalliellidae (represented by a monotypic species restricted to South Africa) [3].

In China, 117 species of the following genera have been identified: Argas (seven species), Carios (four species), and Ornithodoros (two species) in the family Argasidae; and Amblyomma (eight species), Anomalohimalaya (two species), Dermacentor (twelve species), Haemaphysalis

\footnotetext{
*Correspondence: jzliu21@heinfo.net
Key Laboratory of Animal Physiology, Biochemistry and Molecular Biology of

*Correspondence: jzliu21@heinfo.net
Key Laboratory of Animal Physiology, Biochemistry and Molecular Biology of Hebei Province, College of Life Sciences, Hebei Normal University, Shijiazhuang 050024, China
}

(forty four species), Hyalomma (six species), Ixodes (twenty four species), and Rhipicephalus (eight species) in the family Ixodidae [4]. Some of these species carry or transmit one or more infectious pathogens, resulting in severe zoonotic diseases. The most commonly observed human tick-borne diseases in China are reportedly Lyme disease, tick-borne encephalitis, Crimean-Congo hemorrhagic fever, Q fever, tularemia, and North-Asia tick-borne spotted fever [5]. Epidemiologically important tick-borne diseases, such as Human Granulocytic Anaplasmosis (HGA) and severe Fever with Thrombocytopenia Syndrome (FLTS), have also emerged in recent years. The characterization of a new bunyavirus (associated with fever, thrombocytopenia, and leukopenia syndrome) in 2010 has prompted greater attention to ticks and tick-borne diseases throughout China. However, tickassociated pathogens and diseases are still underestimated because of the complex distribution and the large diversity tick species in China.

Although the rapid development of molecular techniques has greatly advanced the identification of emerging tick pathogens, continuous research is required to fully comprehend the diversity of tick-borne pathogens and to completely identify the vector roles of ticks in 
China. In this study, with regard to the Chinese tick fauna, we reviewed the tick-associated pathogenic microorganisms that have been identified world-wide, and evaluated the potential roles of the ticks as vectors throughout China. This will extend the identification of tick-associated pathogens and suggest better strategies for the control of tick-borne diseases in China.

\section{Role of argasid ticks as vectors in China and their associated tick-borne pathogens}

In China, there are 13 species of argasid ticks, belonging to three genera: Argas (seven species), Carios (four species), and Ornithodoros (two species) [4]. The majority of these are nidicolous, usually residing in the burrows, caves, or nests of their hosts. Among all the argasids found in China, four Argas species, two Carios species, and two Ornithodoros species are competent to transmit or cause human disease (Table 1) [6-17]. Among these eight tick species, four (A. japonicas, A. persicus, O. tartakovskyi, and $O$. tholozani) have been confirmed as causing host illnesses in China. A case of human dermatitis was recorded in 1986 after a bite by A. japonicas, but no pathogen has been identified from this tick species in China [6]. The tick A. persicus mainly infests poultry and carries the most diverse array of pathogens in the family Agarsidae, including Borrelia anserine, Kyasanur Forest disease virus, and Wolbachia persica n. sp. However, only B. anserine, known to cause avian spirochetosis, has been confirmed in China [7]. Lake Clarendon virus was isolated from $A$. robertsi; Quaranfil virus and Gissar virus were identified in A. vulgaris; and "Issyk-Kul" virus has been identified in C. vespertilionis. No virus has been detected in ticks collected in China. The symptoms or diseases caused by these viruses are still unclear [11-13,16], and the vector roles of these ticks in China remain unknown.
Carios capensis can be coinfected by pathogen DNA from Borrelia, Coxiella, and Rickettsia, as well as West Nile virus $[14,15]$, although no pathogens have been reported in this tick species collected in China. Ornithodoros tartakovskyi and $O$. tholozani both cause tick-borne relapsing fever in China, but carry different pathogens, B. latyshevyi and B. persica, respectively [17].

\section{Ixodid ticks in China, their roles as vectors, and associated tick-borne pathogens}

There are 104 species of ixodid ticks in China in seven genera: Amblyomma (eight species), Anomalohimalaya (two species), Dermacentor (twelve species), Haemaphysalis (forty four species), Hyalomma (six species), Ixodes (twenty four species), and Rhipicephalus (eight species) [4]. Of these, 52 species from six genera have been shown to carry or transmit pathogenic microorganisms: Ixodes (seven species), Amblyomma (three species), Dermacentor (nine species), Haemaphysalis (twenty one species), Hyalomma (five species), and Rhipicephalus (seven species) (Table 2) [18-114]. Of these 52 species, 32 occur in China (Table 2). Tick-borne spotted fever is the most commonly detected disease, carried by at least 27 tick species. Lyme disease and human granulocytic anaplasmosis are the second and third most widespread tick-borne diseases, transmitted by at least 13 and 10 tick species, respectively (Table 2). Eight tick species are vectors for human granulocytic ehrlichiosis, seven tick species carry tick-borne encephalitis and babesiosis, and six species transmit hemorrhagic fever. The ixodid ticks that act as vectors of Babesia are usually coinfected with more than one Babesia species. These ticks include I. persulcatus, D. nuttalli, Rh. microplus, and Rh. haemaphysaloides, which are often infected by Babesia bigemina and $B a$. bovis (Table 2).

Table 1 Tick-borne pathogens and the vector role of argasid ticks distributed in China

\begin{tabular}{|c|c|c|c|}
\hline Tick species & Pathogens & Diseases & References \\
\hline \multicolumn{4}{|l|}{ Argas } \\
\hline A. japonicas & Unidentified & Dermatitis & [6] \\
\hline A. persicus & $\begin{array}{l}\text { Borrelia anserine; Kyasanur Forest disease virus'; } \\
\text { Wolbachia persica, n. sp. }{ }^{\text {a }}\end{array}$ & Avian spirochetosis; Kyasanur forest disease; Paralysis & {$[7-10]$} \\
\hline A. robertsi & Lake Clarendon virus $^{\mathrm{a}}$ & unknown & [11] \\
\hline A. vulgaris & Quaranfil virus ${ }^{\mathrm{a}}$; Gissar virus ${ }^{\mathrm{a}}$ & unknown & {$[12,13]$} \\
\hline \multicolumn{4}{|l|}{ Carios } \\
\hline C. capensis & West Nile Virus ${ }^{\mathrm{a}, \mathrm{b}}$; Borrelia, Coxiella, and Rickettsia, & West Nile fever & {$[14,15]$} \\
\hline C. vespertilionis & "Issyk-Kul" virusa & unknown & [16] \\
\hline \multicolumn{4}{|l|}{ Orithodorous } \\
\hline O. tartakovskyi & B. latyshevyi & Tick-borne relapsing fever & [17] \\
\hline O. tholozani & B. persiea & Tick-borne relapsing fever & [17] \\
\hline
\end{tabular}

${ }^{a}$ These pathogenic microorganisms have been recorded outside China.

${ }^{\mathrm{b}}$ These pathogenic species have been detected within ticks or have been shown to be transmitted by ticks under controlled experimental conditions. 
Table 2 Tick-borne pathogens and the role of ixodid ticks as vectors within China

\begin{tabular}{|c|c|c|c|}
\hline Tick species & Pathogens & Diseases & References \\
\hline \multicolumn{4}{|l|}{ Ixodes } \\
\hline I. persulcatus & 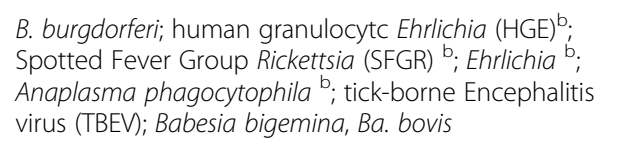 & $\begin{array}{l}\text { Lyme disease; Ehrlichiosis; spotted fever; human } \\
\text { granulocytic anaplasmosis; babesiosis }\end{array}$ & [18-25] \\
\hline I. kazakstani & B. burgdorferi ${ }^{\text {a }}$ & Lyme disease & [26] \\
\hline I. nipponensis & B. afzelii ${ }^{a, b} ;$ TBEV $^{a, b}$ & Lyme disease; tick-borne encephalitis; & {$[27,28]$} \\
\hline 1. ovatus & Ehrlichia ${ }^{\mathrm{a}, \mathrm{b}} ;$ TBEV; R. japonica $a^{\mathrm{a}, \mathrm{b}}$ & $\begin{array}{l}\text { Ehrlichiosis; tick-borne encephalitis; Oriental spotted } \\
\text { fever }\end{array}$ & [29-31] \\
\hline 1. granulates & B. burgdorferi & Lyme disease & [32] \\
\hline 1. acutitarsus & B. burgdorferi & Lyme disease & [33] \\
\hline 1. sinensis & $\begin{array}{l}\text { R. monacensis }{ }^{\text {}} \text {; Ehrlichia, Bartonella, and Borrelia }{ }^{\text {b; }} \\
\text { B. garinii }\end{array}$ & Lyme disease; Mediterranean Spotted Fever & {$[34]$} \\
\hline \multicolumn{4}{|l|}{ Amblyomma } \\
\hline Am. geoemydae & $\begin{array}{l}\text { Reptile-associated Borrelia spp. }{ }^{\mathrm{a}, \mathrm{b}} \text {;relapsing fever } \\
\text { Borrelia sp. }{ }^{\mathrm{a}, \mathrm{b}}\end{array}$ & Relapsing fever & [35] \\
\hline Am. helvolum & SFGR ${ }^{a, b} ;$ Rickettsia sp. $^{\mathrm{a}, \mathrm{b}}$ & Spotted fever & {$[36,37]$} \\
\hline Am. testudinarium & R. tamurae sp. nov. ${ }^{\mathrm{a}, \mathrm{b}}$; Ehrlichia chaffeensis ${ }^{\mathrm{b}}$; & Human monocytic ehrlichiosis & {$[38,39]$} \\
\hline \multicolumn{4}{|l|}{ Haemaphysalis } \\
\hline H. longicornis & 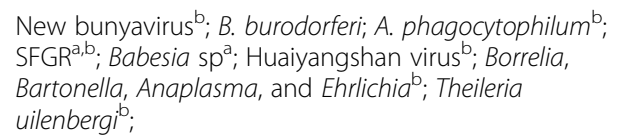 & $\begin{array}{l}\text { Severe fever with thrombocytopenia syndrome; Lyme } \\
\text { disease; human granulocytic anaplasmosis; spotted } \\
\text { fever; babesiosis; Huaiyangshan hemorrhagic fever }\end{array}$ & {$[40-47]$} \\
\hline H. concinna & B. garinii' ; HGE ${ }^{\mathrm{b}}$; SFGR ${ }^{\mathrm{b}}$; $\mathrm{TBEV}^{\mathrm{b}}$ & Human granulocytic Ehrlichiosis & {$[23,48-50]$} \\
\hline H. punctata & $\begin{array}{l}\text { B. burgdorferi sensu stricto }{ }^{b} ; B a \text {. major and T. orientalis; } \\
\text { Crimean-Congo hemorrhagic fever virus } ; \text {; Rickettsia, } \\
\text { R. aeschlimannii, }{ }^{\mathrm{a}, \mathrm{b}} ; \text {; An. phagocytophilum }{ }^{\mathrm{b}} ; \text { Flavivirus }^{\mathrm{b}}\end{array}$ & $\begin{array}{l}\text { Lyme disease; Babesiosis; tick-borne encephalitis; } \\
\text { Crimean-Congo hemorrhagic fever }\end{array}$ & {$[3,51-55]$} \\
\hline H. cornigera & R. heilongjiangensis ${ }^{\mathrm{a}, \mathrm{b}}$ & Spotted fever & [31] \\
\hline H. erinacei & $S F G R^{a, b}$ & Spotted fever & [56] \\
\hline H. flava & Ehrlichia $;$; R. japonica ${ }^{\mathrm{a}, \mathrm{b}}$ & Ehlichiosis; Japanese Spotted fever & {$[57,58]$} \\
\hline H. formosensis & $\begin{array}{l}\text { R. asiatica sp. nov. }{ }^{\mathrm{a}, \mathrm{b}} ; \text { Kyasanur Forest disease virus } \\
\text { R. japonica, }\end{array}$ & Spotted fever; Kyasanur Forest disease; & {$[31,59-61]$} \\
\hline H. hystricis & An. phagocytophilum $;$; R. japonica ${ }^{\mathrm{a}, \mathrm{b}}$ & $\begin{array}{l}\text { Human granulocytic anaplasmosis; Japanese Spotted } \\
\text { fever }\end{array}$ & {$[31,62]$} \\
\hline H. japonica & B. gariniil ; TBEV ${ }^{a, b}$ & Lyme disease; tick-borne encephalitis & {$[63,64]$} \\
\hline H. kitaokai & $S F G R^{a, b}$ & Spotted Fever & [65] \\
\hline H. lagrangei & Anaplasma spp., ${ }^{\mathrm{a}, \mathrm{b}} ;$ Rickettsia $^{\mathrm{a}, \mathrm{b}}$ & Human granulocytic ehrlichiosis; Rickettsioses & {$[66,67]$} \\
\hline H. bispinosa & B. burodorferi; $T$. sergenti; Ba. bigemina & Lyme disease; Piroplasmosis & {$[32,68,69]$} \\
\hline H. megaspinosa & A. bovis and An. phagocytophilum ${ }^{\mathrm{a}, \mathrm{b}} ; \mathrm{SFGR} \mathrm{R}^{\mathrm{a}, \mathrm{b}}$ & Human granulocytic anaplasmosis; spotted fever; & {$[65,70]$} \\
\hline H. ornithophila & SFGR $R^{a, b}$ & Spotted Fever & [71] \\
\hline H. phasiana & $\mathrm{TBEV}^{\mathrm{a}, \mathrm{b}}$ & Tick-borne encephalitis & [64] \\
\hline H. qinghaiensis & T. uilenbergi ${ }^{\text {b; }}$ An. phagocytophilum ${ }^{\text {b; }}$ Theileria spp.; & Human granulocytic anaplasmosis; theileriosis & {$[72-74]$} \\
\hline H. spinigera & Flavivirus ${ }^{\mathrm{a}, \mathrm{b}}$ & Kyasanur forest disease & [3] \\
\hline H. tibetensis & GRD spirochetes & Unknown & {$[75]$} \\
\hline H. wellingtoni & $\begin{array}{l}\text { Kyasanur forest disease virus } \mathrm{s}^{\mathrm{a}, \mathrm{b}} \text {; Eubacterium sp. strain } \\
\text { Hw124 and Eubacterium sp. strain Hw191,a, }\end{array}$ & Kyasanur forest disease; & {$[66,76]$} \\
\hline H. campanulata & Coxiella burnetib & Q fever & [77] \\
\hline H. yeni & R. sibirica $^{\mathrm{b}}$ & North-Asia Spotted fever & {$[78]$} \\
\hline
\end{tabular}


Table 2 Tick-borne pathogens and the role of ixodid ticks as vectors within China (Continued)

\begin{tabular}{|c|c|c|c|}
\hline \multicolumn{4}{|l|}{ Hyalomma } \\
\hline Hy. anatolicum & $\begin{array}{l}\text { Trypanosoma theileri-like flagellates }{ }^{\mathrm{a}, \mathrm{b}} \text {; Crimean-Congo } \\
\text { haemorrhagic fever virus } \mathrm{s}^{\mathrm{a}, \mathrm{b}} ; \text {;. annulata }\end{array}$ & Crimean-Congo haemorrhagic fever & [79-81] \\
\hline Hy. asiaticum & $\begin{array}{l}\text { Hemorrhagic fever virus }{ }^{\mathrm{b}} ; \text { R. mongolotimonae } \\
\text { T. annulata; Rickettsiale }\end{array}$ & Hemorrhagic fever; theileriosis & {$[81-84]$} \\
\hline Hy. scupense & T. annulata & Theileriosis & [81] \\
\hline Hy. rufipes & T. annulata $a^{a, b}$ & Theileriosis & [85] \\
\hline Hy. dromedarii & Kadam virus ${ }^{\mathrm{a}, \mathrm{b}}$ & Unknown & {$[86]$} \\
\hline \multicolumn{4}{|l|}{ Dermacentor } \\
\hline D. nuttalli & $\begin{array}{l}\text { B. burgdorferi } i^{\text {b }} \text { SFGR }{ }^{\text {b }} \text { HGE; Ba. caballi and Ba. equi }{ }^{\mathrm{a}, \mathrm{b}} \text {; } \\
\text { Rickettsiaes }\end{array}$ & $\begin{array}{l}\text { Lyme disease; North Asia Spotted Fever; human } \\
\text { granulocytic ehrlichiosis; babesiosis }\end{array}$ & {$[23,84,87-89]$} \\
\hline D. reticulatus & $\begin{array}{l}\text { R. helvetica } a, b \text {; R. slovaca }{ }^{a, b} \text {; An. phagocytophila }{ }^{a, b} \text {; } \\
\text { Babesia } a^{a, b}\end{array}$ & $\begin{array}{l}\text { Unexplained febrile illness; Spotless rickettsiosis; } \\
\text { human granulocytic anaplasmosis; babesiosis }\end{array}$ & {$[90-93]$} \\
\hline D. silvarum & 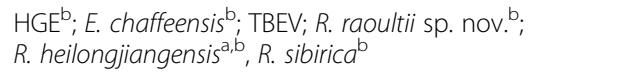 & $\begin{array}{l}\text { Human granulocytic ehrlichiosis; Encephalitis; Spotted } \\
\text { Fever; }\end{array}$ & {$[23,94-98]$} \\
\hline D. auratus & $S F G R^{b}$ & Spotted Fever & [99] \\
\hline D. everestianus & An. ovis $;$; R. raoultii-like bacteria ${ }^{\mathrm{b}}$; Bacillus tularensis ${ }^{\mathrm{b}}$ & Spotted Fever; Tularemia & {$[100-102]$} \\
\hline D. marginatus & B. burgdorferib; R. slovaca, a, & Lyme disease; tick-borne lymphadenopathy & {$[51,103]$} \\
\hline D. niveus & SFGR ${ }^{\mathrm{a}, \mathrm{b}} ;$ An. ovis ${ }^{\mathrm{b}} ;$ Bacillus tularensis $^{\mathrm{b}}$ & Spotted Fever; Tularemia & {$[100,102,104]$} \\
\hline D. sinicus & $S F G R^{b}$ & Spotted fever & {$[105]$} \\
\hline D. taiwanensis & R. japonica ${ }^{a, b}$ & Japanese Spotted fever & [106] \\
\hline \multicolumn{4}{|l|}{ Rhipicephalus } \\
\hline Rh. microplus & $\begin{array}{l}\text { A. marginale }{ }^{b}, \text { Ba. bigemina, Ba. bovis, T. equi; } E \text {. } \\
\text { chaffeensis, }^{a, b} ; \mathrm{TBEV}^{\mathrm{b}} ; \mathrm{C} \text {. burnetii }\end{array}$ & Babesiosis; theileriosis; Encephalitis; Q fever & {$[2,107,108]$} \\
\hline Rh. bursa & $\begin{array}{l}\text { An. marginale }{ }^{\mathrm{b}}, \text { An. ovis } \mathrm{s}^{\mathrm{b}}, \text { An. phagocytophilum } \\
\text { bigemina }^{\mathrm{b}}, \mathrm{Ba} \text {. Ba. ovis } \\
\text { hemorrhagic fever virus }^{\mathrm{a}, \mathrm{b}}\end{array}$ & $\begin{array}{l}\text { Human granulocytic anaplasmosis; babesiosis; } \\
\text { Crimean-Congo hemorrhagic fever }\end{array}$ & {$[3,109]$} \\
\hline Rh. pumilio & $\mathrm{SFGR}^{\mathrm{a}, \mathrm{b}} ;$ R. conorii $;$; An. phagocytophilum ${ }^{\mathrm{b}}$ & Spotted fever; human granulocytic anaplasmosis & {$[110,111]$} \\
\hline Rh. rossicus & West Nile virus ${ }^{\mathrm{a}, \mathrm{b}}$ & West Nile fever & [112] \\
\hline Rh. sanguineus & $\begin{array}{l}\text { Ba. vogeli }{ }^{\mathrm{b}}, \text { E. canis }{ }^{\mathrm{b}}, \text { R. conorii }{ }^{\mathrm{a}, \mathrm{b}}, \text { R. massiliae } \\
\text { R. rickettsii, }\end{array}$ & Babesiosis; Mediterranean spotted fever & {$[3,113]$} \\
\hline Rh. turanicus & R. conori ${ }^{\mathrm{a}, \mathrm{b}}$, R. massiliae $e^{\mathrm{a}, \mathrm{b}}$ & Mediterranean spotted fever & [114] \\
\hline $\begin{array}{l}\text { Rh. } \\
\text { haemaphysaloides }\end{array}$ & $\mathrm{SFGR}^{\mathrm{b}} ;$ Ba. bigemina ${ }^{\mathrm{b}}$, B. bovis ${ }^{\mathrm{b}}$ & Spotted fever; Babesiosis & [109] \\
\hline
\end{tabular}

${ }^{\text {a }}$ These pathogenic microorganisms have been recorded outside China.

${ }^{\mathrm{b}}$ These pathogenic species have been detected within ticks or have been shown to be transmitted by ticks under controlled experimental conditions.

\section{Genus Ixodes}

Ixodes persulcatus is undoubtedly the most notorious tick within China, and is known to carry a wide range of microorganisms, including Borrelia, Ehrlichia, Rickettsia, Anaplasma, and Babesia [18-25]. Lyme disease is mainly transmitted by Ixodes ticks, and Borrelia spp. have been isolated from or detected in I. persulcatus, I. kazakstani, I. nipponensis, I. granulates, I. acutitarsus, and I. sinesis in China [18,26,27,32-34]. Tick-borne encephalitis virus is carried by I. persulcatus, I. nipponensis, and I. ovatus $[24,28,30]$, whereas spotted fever can only be transmitted by $I$. persulcatus and I. ovatus [20,31].

Among these Ixodes species, only I. kazakstani and I. nipponensis have not yet been shown to carry Lyme disease in China, because $B$. burgdorferi has not been found in I. kazakstani collected in China [26], and B. afzelii has not been detected in I. nipponensis distributed in China [28]. Although their pathogens have not been confirmed in China, the vector roles of these ticks are widely recognized [26,28]. Tick-borne encephalitis virus has not been found in I. kazakstani in China [27], whereas Ehrlichia and R. japonica have only been found in the species I. ovatus, distributed outside China [29,31].

\section{Genus Amblyomma (Am.)}

Amblyomma geoemydae [35], Am. helvolum [36,37], and Am. testudinarium [38,39], collected from Japan, Thailand, and China, are known to carry pathogen DNA from 
Borrelia, Rickettsia, and Ehrlichia, respectively. However, although all these species are found in China, $E$. chaffeensis, detected in Am. testudinarium, is the only bacterial species that has been found in specimens collected within China [38].

\section{Genus Haemaphysalis}

The majority of ixodid ticks found in China belong to the genus Haemaphysalis. Globally, 21 of the 44 species found within China are known to be associated with pathogens. Of these 21 species, 11 ( $H$. longicornis, $H$. concinna, $H$. punctata, $H$. flava, $H$. hystricis, $H$. japonica, $H$. bispinosa, $H$. qinghaiensis, $H$. tibetensis, $H$. campanulata, and $H$. yeni) have been confirmed as pathogen vectors in China (Table 2) [40-78]. The most commonly detected diseases vectored by this genus of ticks are spotted fever and human granulocytic anaplasmosis, which are transmitted by 11 and six species, respectively. Borrelia is carried by at least five species of this genus, and Babesia by at least four species (Table 2).

The ticks $H$. longicornis, $H$. punctata, and $H$. concinna support the greatest diversity of pathogenic microorganisms, with $H$. longicornis the major vector of B. burgdorferi, Theileria spp., Coxiella burnetti, Babesia spp., Anaplasma phagocytophilum, Ehrlichia, Bartonella, spotted-fevergroup rickettsiae, Huaiyangshan virus, and the recently identified New bunyavirus (Table 2), which has caused many deaths in China, Japan, and Korea [40-47]. Haemaphysalis concinna is mainly distributed in northern China, where multiple outbreaks of $H$. concinna-borne disease have been reported since the early 20 th century. These outbreaks have been attributed to a diverse array of pathogens, including B. garinii, human granulocytic Ehrlichia, spotted-fever-group Rickettsiae, and encephalitis viruses [23,48-50]. Haemaphysalis punctata transmits B. burgdorferi sensu stricto, Ba. major, T. orientalis, Crimean-Congo hemorrhagic fever virus, Rickettsia, $R$. aeschlimannii, An. phagocytophilum, and Flavivirus, resulting in diseases such as Lyme disease, babesiosis, tick-borne encephalitis, and Crimean-Congo hemorrhagic fever [3,51-55]. Haemaphysalis formosensis has been shown to carry pathogen DNA from a number of bacterial species, including $R$. asiatica sp. nov., Kyasanur Forest disease virus, $R$. japonica, and An. phagocytophilum, but these pathogens have not yet been detected in this tick species within China. Among the pathogenic microorganisms transmitted by Haemaphysalis species, most have been characterized with molecular techniques, and some species have been shown to transmit particular pathogens under controlled experimental conditions (Table 2).

\section{Genus Hyalomma (Hy.)}

Five species of Hyalomma are known to harbor pathogenic microorganisms (Table 2) [79-86], and three have been confirmed as vectors within China: Hy. anatolicum, Hy. asiaticum, and Hy. scupense. Hyalomma anatolicum and Hy. asiaticum carry the greatest diversity of pathogens, and each transmits at least three pathogens. Theileria annulata is the most common pathogenic microorganism, and is transmitted by four of the five Hyalomma vector ticks (Hy. anatolicum, Hy. asiaticum, Hy. scupense, and Hy. rufipes) [79,85]. Trypanosoma theileri-like flagellates and Crimean-Congo hemorrhagic fever virus have been detected in Hy. anatolicum outside China, whereas T. annulata was characterized from Hy. anatolicum within China [79-81]. Hemorrhagic fever virus and $R$. mongolotimonae were detected in Hy. asiaticum in north China [81-83], and Hy. asiaticum is the only tick species that can transmit Rickettsiae [84]. Hyalomma dromedarii has been shown to transmit Kadam virus outside China, although the resulting symptoms are still unknown [86].

\section{Genus Dermacentor}

Nine of the 12 species of Dermacentor found within China can transmit pathogens, and seven of these species (D. nuttali, D. silvarum, D. auratus, D. everestianus, D. marginatus, D. niveus, and D. sinicus) are of epidemiological importance in China (Table 2) [23,84-106]. The widely distributed $D$. nuttalli, D. reticulates, and $D$. silvarum carry the largest numbers of different pathogenic microorganisms, and Rickettsiae are the most commonly found bacteria in this genus (Table 2). The causative agent of human granulocytic ehrlichia has been detected in $D$. silvarum and D. nuttalli within China [23], and Babesia is commonly found in $D$. nuttalli and D. reticulatus outside China [89]. Borrelia burgdorferi has been found in $D$. marginatus [51] and D. nuttalli within China [87]; An. ovis and Bacillus tularensis are most commonly found in D. everestianus [100] and D. niveus within China [104]; and An. phagocytophila is specifically detected in $D$. reticulatus outside China [92].

\section{Genus Rhipicephalus (Rh.)}

In the genus Rhipicephalus, seven tick species are known to harbor pathogenic microorganisms, and five of these species (Rh. microplus, Rh. bursa, Rh. pumilio, Rh. sanguineus, and $R h$. haemaphysaloides) are confirmed vectors in China (Table 2) [107-114]. Rhipicephalus microplus and Rh. bursa carry the largest numbers of different pathogens in this genus. Ehrlichia chaffeensis, Bhanja virus, and Crimean-Congo hemorrhagic fever virus have not yet been detected in Rh. microplus or Rh. bursa within China. Babesia is the most common microorganism transmitted by $R h$. microplus [2], Rh. bursa, Rh. sanguineus [3], and Rh. haemaphysaloides [109], and various Rickettsia species have been found in $R h$. pumilio [110], Rh. sanguineus, $R h$. haemaphysaloides, and $R h$. turanicus. West Nile virus and Crimean-Congo hemorrhagic fever virus have been 
characterized solely in $R h$. rossicus [112] and Rh. bursa [109], respectively, whereas Ehrlichia has been found in both Rh. microplus [107] and Rh. sanguineus [113]. Anaplasma marginale, An. ovis, and An. phagocytophilum can be acquired by $R h$. bursa $[3,113]$. Among these bacterial species, no spotted-fever-group Rickettsia has been detected in Rh. pumilio collected in China; West Nile virus has not been characterized in $R h$. rossicus within China; $R$. conori, $R$. massiliae, and $R$. rickettsii have not been detected in $R h$. sanguineus in China; and $R$. massiliae has not been detected in Rh. turanicus within China.

\section{Conclusion}

Of the estimated 117 species of ticks in China, 36 have been confirmed to carry or transmit one or more pathogens, and 24 additional species are known to be pathogenic vectors in other countries. Furthermore, 38 species have been shown to carry multiple pathogens, indicating the major roles they play in the spread and transmission of these pathogens. Therefore, the number of pathogens and the vector potential of ticks may still be underestimated, because of the complex distributions and the great diversity of tick species in diverse ecological habitats in China. However, such knowledge will provide clues to the further identification of tick-associated pathogens, especially in epidemic areas with multiple tick species. Much more work is required to better distinguish between ticks that carry potential pathogens and those that are competent to transmit pathogens to a host. Targeted prevention methods will then be more effective in controlling tick-borne diseases.

\section{Competing interests}

The authors declare that they have no competing interests.

\section{Authors' contributions}

YZ-J and LJ-Z conceived and designed the study, drafted the manuscript, and critically revised the manuscript. W H, W T-H, S W-Y and YX-L participated in data collection and helped to revise the manuscript. All authors read and approved the final manuscript.

\section{Acknowledgements}

We would like to thank Dr. Alexander Smith from the Department of Biological Sciences at the University of Alberta, Canada for English editing. This work was supported by National Natural Science Foundation of China (31400342, 31272372), the Specialized Research Fund for the Doctoral Program of Higher Education of China (20131303130001), Natural Science Research Programs of Educational Department of Hebei Province (Q2012072), and Science Foundation of Hebei Normal University (L2012Z05; L2011B13).

Received: 13 October 2014 Accepted: 29 December 2014 Published online: 14 January 2015

\section{References}

1. de la Fuente J, Estrada-Pena A, Venzal JM, Kocan KM, Sonenshine DE. Overview: Ticks as vectors of pathogens that cause disease in humans and animals. Front Biosci. 2007;13:6938-46.

2. Jongejan F, Uilenberg G. The global importance of ticks. Parasitology. 2004;129:53-14.
3. Dantas-Torres F, Chomel BB, Otranto D. Ticks and tick-borne diseases: a one health perspective. Trends Parasitol. 2012;28:437-46.

4. Chen Z, Yang XJ, Bu FJ, Yang XH, Yang XL, Liu JZ. Ticks (Acari: Ixodoidea: Argasidae, Ixodidae) of China. Exp Appl Acarol. 2010;51:393-404.

5. Wu XB, Na RH, Wei SS, Zhu JS, Peng HJ. Distribution of tick-borne diseases in China. Parasit Vectors. 2013;6:119.

6. Li WX, Du XJ, Zhong DA. Investigation on human dermatitis caused by Argas japonicasin bedroom. Chin J Parasitol Parasit Dis. 1986;4:77 (in Chinese).

7. Liu K, Ding XY, Chen LY, Mei JJ, Zhai LJ. A case report on the diagnosis of gosling spirochetosis. Jilin Anim Husb Vet Med. 2006;27:42-3 (in Chinese).

8. Singh KR, Goverdhan MK, Bhat UK. Transmission of Kyasanur Forest disease virus by soft tick, Argas persicus (Ixodoidea: Argasidae). Indian J Med Res. 1971:59:213-8

9. Rosenstein M. Paralysis in chickens caused by larvae of the poultry tick, Argas persicus. Avian Dis. 1976;20:407-9.

10. Suitor EC, Weiss E. Isolation of a Rickettsia-like microorganism (Wolbachia Persica, N. SP.) from Argas persicus (Oken). J Infect Dis. 1961;108:95-106.

11. George TDS, Cybinski DH, Main AJ, McKilligan N, Kemp DH. Isolation of a new arbovirus from the tick Argas robertsi from a cattle egret (Bubulcus ibis coromandus) colony in Australia. Aust J Biol Sci. 1984;37:85-90.

12. Klein JM, Sureau P, Casals J, Piazak N, Korouri C, Calvo MA. Isolation of Quaranfil virus in Iran from ticks Argas vulgaris (Argasidae, arbovirus). Cahiers-ORSTOM Serie Entomologie Medicale et Parasitologie. 1980;17:201-6.

13. Gordeeva ZE, Kostyukov MA, Küma AU, Daniyarov OA, Bulychev VP, Nemova NV, et al. Gissar virus-a new virus of the family Bunyaviridae isolated from the argasid tick Argas vulgaris Fil. in Tajikistan. Meditsinskaya Parazitologiya i Parazitarnye Bolezni. 1990;6:34-5.

14. Hutcheson HJ, Gorham CH, Machain-Williams C, Loroño-Pino MA, James $\mathrm{AM}$, Marlenee NL, et al. Experimental transmission of West Nile virus (Flaviviridae: Flavivirus) by Carios capensis ticks from North America. VectorBorne Zoonotic Dis. 2005;5:293-5.

15. Reeves WK, Loftis AD, Sanders F, Spinks MD, Wills W, Denison AM, et al. Borrelia, Coxiella, and Rickettsia in Carios capensis (Acari: Argasidae) from a brown pelican (Pelecanus occidentalis) rookery in South Carolina, USA. Exp Appl Acarol. 2006:39:321-9.

16. Lvov DK, Karas FR, Timofeev EM, Tsyrkin YM, Vargina SG, Veseloskaya OV, et al. "Issyk-Kul" virus, a new arbovirus isolated from bats and Argas (Carios) vespertilionis (Latr., 1802) in the Kirghiz SSR. Arch Virol. 1973;42:207-9.

17. Shao GN. Methods on investigation of the epidemic focus of tick-borne relapsing fever. People's Mil Sur. 1982;3:17-9 (in Chinese).

18. Cao YX, Zhang XT, Ma J, Zhang YG, Qian JQ, Wei GH. Borrelia burgdorferi isolated from Ixodes persulcatus in Xinjiang. Endemic Dis Bull. 1988;4:13-5 (in Chinese).

19. Zhang ZQ, Wu YM, Feng L, Wang H, Yu M, Wang Z. Molecular epidemiology investigation on DNA of Ehrlichia in ticks in border region. Chin J Epidemiol. 2010;10:41-3 (in Chinese).

20. Tang K, Zuo SY, Zheng YC. Dynamic investigation on the co-infection status of two pathogens in ticks from tourist point in Heilongjiang province. Chin J Epidemiol. 2012;33:508-11 (in Chinese).

21. Fu WM, Ding DW, Li M, Cui ZQ, Zhao W, Cui YM. Preliminary investigation on the Anaplasma phagocytophilum infection in the ticks from Port Areas of Heilongjiang Province, China. Acta Parasitol Med Entomol Sin. 2010;17:152-6 (in Chinese).

22. Zhao JX. Epidemiological investigation and prevention research of bovine babesiosis in Turpan. Urumqi: Xinjiang Agriculture University; 2012. in Chinese.

23. Gao DQ, Cao WC, Zhang XT, Zhao QM, Tong YG. The amplfying methods and application of the 16S rRNA genes of two kinds of human Ehrilichia species. Acta Parasitol Med Entomol Sin. 2000;8:175-80 (in Chinese).

24. Yan DC, Li YG, Wang SY, Chen LF, Ren GS, Liu YC. First detection of tickborne encephalitis virus in Daxing' anling forest regions, Inner Mongolia. Inner Mongolia Med J. 1996;7:65-7 (in Chinese).

25. Zhao QM, Cao WC, Zhang XT, Gao DQ, Zhang BH, Luo SF, et al. Detection of HE-like pathogen in Ixodes persulcatus collected from Heilongjiang. Chin J Zoonoses. 2001;17:28-30 (in Chinese).

26. Lane RS, Piesman J, Burgdorferi W. Lyme borreliosis: Relation of its causative agent to its vectors and hosts in North America and Europe. Ann Rev Entomol. 1991;36:587-609.

27. Lee S, Jung K, Lee J, Kim S, Kim J, Jang W, et al. Characterization of Borrelia afzelii isolated from Ixodes nipponensis and Apodemus agrarius in Chungju, 
Korea, by PCR-RFLP analyses of ospC gene and rrf (5S)-rrl (23S) intergenic spacer. Microbiol Immunol. 2002;46:677-83.

28. Kim S, Yun S, Han MG, Lee IY, Lee NY, Jeong YE, et al. Isolation of tick-borne encephalitis viruses from wild rodents, South Korea. Vector-borne Zoonotic Dis. 2008:8:7-14.

29. Shibtata SH, Kawahara M, Rikihisa Y, Fujita H, Watanabe Y, Suto C, et al. New Ehrlichia species closely related to Ehrlichia chaffeensis isolated from Ixodes ovatus ticks in Japan. J Clin Microbiol. 2000;38:1331-8.

30. Hou ZL, Huang WL, Bai D, Gong ZD, Lei YM. First characterization of tick-borne encephalitis virus from rodents and insectivores. Virol Sin. 1992;7:397-403 (in Chinese).

31. Ando S, Kurosawa M, Sakata A, Fujita H, Sakai K, Sekine M, et al. Human Rickettsia heilongjiangensis infection, Japan. Emerg Infect Dis. 2010;16:1306-8.

32. Wan KL, Zhang ZF, Dou GL, Hou XX, Wang HY, Zhang JS, et al. Investigation on primary vectors of Borrelia burgdorferi in China. Chin J Epidemiol. 1998;19:263-6 (in Chinese).

33. Sun Y, Xu RM. Experimental animal model of Lyme disease. Acta Parasitol Med Entomol Sin. 2001:8:20-6 (in Chinese).

34. Sun Y, Xu RM, Ge XF, Lu BL, Liu ZJ. Ability of Ixodes sinensis Teng, Haemaphysalis yeni Toumanoff and H.ginghaiensis Teng (Acari: Ixodidae) to transmit Borrelia garinii transstadially. Acta Entomol Sin. 2003;46:667-73 (in Chinese).

35. Takano A, Sugimori C, Fujita H, Kadosaka T, Taylor KR, Tsubota T, et al. A novel relapsing fever Borrelia sp. infects the salivary glands of the molted hard tick, Amblyomma geoemydae. Ticks Tick-borne Dis. 2012;3:259-61.

36. Sumrandee C, Hirunkanokpun S, Doornbos K, Kitthawee S, Baimai V, Grubhoffer $\mathrm{L}$, et al. Molecular detection of Rickettsia species in Amblyomma ticks collected from snakes in Thailand. Ticks Tick-borne Dis. 2014;5:632-40

37. Doornbos K, Sumrandee C, Ruang-Areerate T, Baimai V, Trinachartvanit W, Ahantarig A. Rickettsia sp. closely related to Rickettsia raoultii (Rickettsiales: Rickettsiaceae) in an Amblyomma helvolum (Acarina: Ixodidae) tick from a Varanus salvator (Squamata: Varanidae) in Thailand. J Med Entomol. 2013;50:217-20.

38. Cao WC, Gao YM, Zhang PH, Zhang XT, Dai QH, Dumler JS, et al. Identification of Ehrlichia chaffeensisby nested PCR in ticks from southern China. J Clin Microbiol. 2000;38:2778-80.

39. Fournier PE, Takada N, Fujita H, Raoult D. Rickettsia tamurae sp. nov., isolated from Amblyomma testudinarium ticks. Int J of Syst Evol Microbiol. 2006;56:1673-5.

40. Liu Y. Survey on ticks and detection of new bunyavirus in the endemic areas of fever, thrombocytopenia and leucopenia syndrome in Henan province. Zhengzhou: Zhengzhou University; 2012. in Chinese.

41. Liao DF, Chen JW, Xie P, Fu PP, Zhu ZQ. Progress in researches on the Lyme disease spirochete Borrelia burgdoferi. Chin J Vet Parasitol. 2004;12:36-9 (in Chinese).

42. Zhang LJ. Progress in research of Anaplasma phagocytophilum and anaplasmosis in China. Dis Survil. 2014;29:409-14 (in Chinese).

43. Lee JH, Park HS, Jung KD, Jang WJ, Koh SE, Kang SS, et al. Identification of the spotted fever group rickettsiae detected from Haemaphysalis longicornis in Korea. Microbiol Immunol. 2003;47:301-4.

44. Tsuji N, Battsetseg B, Boldbaatar D, Miyoshi T, Xuan XN, Oliver Jr JH, et al. Babesial vector tick defensin against Babesia sp. parasites. Infect Immu. 2007;75:3633-40

45. Zhang YZ, Zhou DJ, Qin XC, Tian JH, Xiong YW, Wang JB, et al. The ecology, genetic diversity, and phylogeny of Huaiyangshan virus in China. J Virol. 2012;86:2864-8.

46. Sun JM, Liu QY, Lu L, Ding GQ, Guo JQ, Fu GM, et al. Coinfection with four genera of bacteria (Borrelia, Bartonella, Anaplasma, and Ehrlichia) in Haemaphysalis longicornis and Ixodes sinensis ticks from China. Vector-Borne Zoonotic Dis. 2008;8:791-6.

47. Li YQ, Luo JX, Guan GQ, Ma ML, Liu AH, Liu JL, et al. Experimental transmission of Theileria uilenbergi infective for small ruminants by Haemaphysalis longicornis and Haemaphysalis qinghaiensis. Parasitol Res. 2009;104:1227-31.

48. Sun Y, Xu RM. Ability of /xodes persulcatus, Haemaphysalis concinna and Dermacentor silvarum ticks to acquire and transstadially transmit Borrelia garinii. Exp Appl Acarol. 2003;31:151-60.

49. Zhang JZ, Fan MY, Bi DZ, Song XP. Isolation and identification of new species of Spotted Fever Group Rickettsiae. Chin J Zoonoses. 1996;12:2-8 (in Chinese).
50. Cai ZL, Lu ZX, Hu LM, Zhao ZL, Jin XT, He YX. Epidemiology survey of Russian-Spring summer encephalitis in the northeast areas, China. J Micobiol. 1996;16:19-22 (in Chinese).

51. Zhang L, Wang YZ, Chen CF, Li YX, Zhang K, Du JY, et al. Isolation of Borrelia burgdorferi in ixodes from four counties, in North Xinjiang. Chin J Epidem. 2014;35:262-5 (in Chinese).

52. L'Hostis M, Seegers H. Tick-borne parasitic diseases in cattle: current knowledge and prospective risk analysis related to the ongoing evolution in French cattle farming systems. Vet Res. 2002;33:599-611.

53. Hoogstraal $\mathrm{H}$. The epidemiology of tick-borne Crimean-Congo hemorrhagic fever in Asia, Europe, and Africa. J Med Entomol. 1979;15:307-417.

54. Yin H, Lu W, Luo JX. Babesiosis in China. Trop Animal Health Pro. 1997;29:11S-5

55. Fernández SP, Encinas GA, Pérez SR. Rickettsia aeschlimannii in Spain: molecular evidence in Hyalomma marginatum and five other tick species that feed on humans. Emerg Infect Dis. 2003;9:889-90.

56. Khaldi M, Socolovschi C, Benyettou M, Barech G, Biche M, Kernif T, et al. Rickettsiae in arthropods collected from the North African Hedgehog (Atelerix algirus) and the desert hedgehog (Paraechinus aethiopicus) in Algeria. Comp Immunol Microbiol Infect Dis. 2012;35:117-22.

57. Wen B, Jian R, Zhang YZ, Chen R. Simultaneous detection of Anaplasma marginale and a new Ehrlichia species closely related to Ehrlichia chaffeensis by sequence analyses of 165 ribosomal DNA in Boophilus microplus ticks from Tibet. J Clin Microbiol. 2002;40:3286-90.

58. Fournier PE, Fujita H, Takada N, Raoult D. Genetic identification of rickettsiae isolated from ticks in Japan. J Clin Microbiol. 2002;40:2176-81.

59. Fujita H, Fournier PE, Takada N, Saito T, Raoult D. Rickettsia asiatica sp. nov., isolated in Japan. Int J Syst Evol Microbiol. 2006;56:2365-8.

60. Mehla R, Kumar SR, Yadav P, Barde PV, Yergolkar PN, Erickson BR, et al. Recent ancestry of Kyasanur Forest disease virus. Emerg Infect Dis. 2009;15:1431-7.

61. Gaowa W, Wu D, Yoshikawa Y, Ohashi N, Kawamori F, Sugiyama K, et al. Detection and characterization of $\mathrm{p} 44 / \mathrm{msp} 2$ transcript variants of Anaplasma phagocytophilum from naturally infected ticks and wild deer in Japan. Jpn J Infect Dis. 2012;65:79-83.

62. Fu XP, Wang JQ, He JR, Zhang JS. Establishment of real-time PCR assay to detect Anaplasma phagocytophilum Msp2 gene with TaqMan MGB probe. Dis Surveil. 2012;27:141-4 (in Chinese).

63. Li ZQ, Liu ZJ, Gong ZW, Zhang F, Fei JX, Liu T, et al. Molecular epidemiological studies on Borrelia burgdorferii infection in ticks from Shannxi Province. Acta Parasitol Med Entomol Sin. 2010;17:148-51 (in Chinese).

64. Ko S, Kang JG, Kim SY, Kim HC, Klein TA, Chong ST, et al. Prevalence of tick-borne encephalitis virus in ticks from southern Korea. J Vet Sci. 2010;11:197-203.

65. Ishikura M, Ando S, Shinagawa Y, Matsuura K, Hasegawa S, Nakayama T, et al. Phylogenetic analysis of spotted fever group Rickettsiae based on gltA, $17-\mathrm{kDa}$, and rOmpA genes amplified by nested PCR from ticks in Japan. Microbiol Immunol. 2003;47:823-32.

66. Parola P, Cornet JP, Sanogo YO, Miller RS, Thien HV, Gonzalez JP, et al. Detection of Ehrlichia spp., Anaplasma spp., Rickettsia spp., and other eubacteria in ticks from the Thai-Myanmar border and Vietnam. J Clin Microbiol. 2003;41:1600-8.

67. Ahantarig A, Malaisri P, Hirunkanokpun S, Sumrandee C, Trinachartvanit W, Baimai V. Detection of Rickettsia and a novel Haemaphysalis shimoga symbiont bacterium in ticks in Thailand. Curr Microbiol. 2011;62:1496-502.

68. Liu ZY, Ma YL, Ma TL, Guan MH, Gao GZ, Cao CY, et al. Research on the transmission ability of Theileria sergenti by Haemaphysalis bispinosa in Jian of Jilin Province. Vet Sci China. 1982;11:28-31 (in Chinese).

69. Wu WH, Yang MS, Liao M, Yang L, Jia HJ. Diagnose and analysis on cattle babesiosis caused by Babesia bigemina. Shanghai J Animal Husb and Vet Med. 2008;1:112-4 (in Chinese).

70. Yoshimoto K, Matsuyama Y, Matsuda H, Sakamoto L, Matsumoto K, Yokoyama N, et al. Detection of Anaplasma bovis and Anaplasma phagocytophilum DNA from Haemaphysalis megaspinosa in Hokkaido, Japan. Vet Parasitol. 2010;168:170-2.

71. Hirunkanokpun S, Kittayapong P, Cornet JP, Gonzalez JP. Molecular evidence for novel tick-associated spotted fever group rickettsiae from Thailand. J Med Entomol. 2003:40:230-7.

72. Yuan YQ. Evaluation of the humour-mediated immunity induced by recombinant antigen TulP against ovine and caprine theileriosis. Lanzhou: Chinese Academy of Agricultural Sciences; 2013. in Chinese. 
73. Yang J, Liu ZJ, Guan GQ, Liu Q, Li YQ, Chen Z, et al. Prevalence of Anaplasma phagocytophilum in ruminants, rodents and ticks in Gansu, north western China. J Med Microbiol. 2013;62:254-8.

74. Yin H, Guan GQ, Ma ML, Luo JX, Lua BY, Yuan GL, et al. Haemaphysalis ginghaiensis ticks transmit at least two different Theileria species: one is infective to yaks, one is infective to sheep. Vet Parasitol. 2002;107:29-35.

75. Zhang PH, Cao JT, Li YC, Zhang QE. Ultra structure observation of newly GRD spirochetes isolate in Tibet. Corpus Epidemiol Invest. 1996;2:62-6 (in Chinese)

76. Bhat HR, Naik SV. Transmission of Kyasanur forest disease virus by Haemaphysalis wellingtoni Nuttall and Warburton, 1907 (Acarina: Ixodidae). Indian J Med Res. 1978;67:697-703.

77. Liu LZ, Li GP, Yu SR. Research on the experimental infection of Q-fever rickettsiae against Haemaphysalis canipanulata. Acta Acad Med Mil Tert 1980;2:17-21 (in Chinese).

78. Chen M, Fan M. A review on the research of North-Asia tick-borne spotted fever. Chinese J Public Health. 1997;6:373-6 (in Chinese).

79. Morzaria SP, Latif AA, Jongejan F, Walker AR. Transmission of a Trypanosoma sp. to cattle by the tick Hyalomma anatolicum anatolicum. Vet Parasitol. 1986;19:13-21.

80. Williams RJ, Busaidy S, Mehta FR, Maupin GO, Wagoner KD, Awaidy SA, et al. Crimea-Congo haemorrhagic fever: a seroepidemiological and tick survey in the Sultanate of Oman. Trop Med Int Health. 2000;5:99-106.

81. Liu AH, Guan GQ, Liu JL, Li YQ, Ma ML, Niu QL, et al. Isolation and identification of the piroplasma species transmitted by Hyalomma scupense and preliminary study on its biological characteristics. Prog Vet Med. 2009:30:17-20 (in Chinese).

82. Xiao CE. Investigation on the vector host of hemorrhagic fever in Xinjiang Endemic Dis Bull. 2004;19:50-4 (in Chinese).

83. Yu X, Fan M, Xu G, Liu Q, Raoult D. Genotypic and antigenic identification of two new strains of spotted fever group rickettsiae isolated from China. J Clin Microbiol. 1993:31:83-8.

84. Kang YJ, Diao XN, Zhao GY, Chen MH, Xiong YW, Shi M, et al. Extensive diversity of Rickettsiales bacteria in two species of ticks from China and the evolution of the Rickettsiales. BMC Evol Biol. 2014;14:167.

85. Dipeolu OO, Ogunji FO. The transmission of Theileria annulata to a rabbit by the larvae of the tick Hyalomma rufipes. Lab Anim. 1977;11:39-40.

86. Wood OL, Moussa MI, Hoogstraal H, Büttiker W. Kadam virus (Togaviridae, flavivirus) infecting camel-parasitizing Hyalomma dromedarii ticks (Acari: Ixodidae) in Saudi Arabia. J Med Entomol. 1982;19:207-8.

87. Sun Y, Xu RM, Guo TY, Zhang BH, Cao WC. Failure to transmit Lyme spirochetes transstadially in Dermacentor silvarum and D. nuttall (Acari: Ixodidae). Acta Entomol Sin. 2002:45:578-82 (in Chinese).

88. Fan MY, Yu XJ, Bi DZ, Zhao LC, Zhang ML, Zong DG, et al. Study on molecular epidemiology of North Asia Tick Borne Spotted Fever in China. Chin J Pub Health. 1992;11:67-72 (in Chinese)

89. Battsetseg B, Xuan X, Ikadai H, Bautista JL, Byambaa B, Boldbaatar D, et al. Detection of Babesia caballi and Babesia equi in Dermacentor nuttalli adult ticks. Int J Parasitol. 2001;31:384-6.

90. Dobec M, Golubic D, Punda-Polic V, Kaeppeli F, Sievers M. Rickettsia helvetica in Dermacentor reticulatus ticks. Emerg Infect Dis. 2009;15:98-100.

91. Raoult D, Lakos A, Fenollar F, Beytout J, Brouqui P, Fournier PE. Spotless rickettsiosis caused by Rickettsia slovaca and associated with Dermacentor ticks. Clin Infect Dis. 2002;34:1331-6.

92. Sixl W, Petrovec M, Marth E, Wüst G, Stünzner D, Schweiger R, et al. Investigation of Anaplasma phagocytophila infections in Ixodes ricinus and Dermacentor reticulatus ticks in Austria. Ann N Y Acad Sci. 2003;990:94-7.

93. Rar VA, Maksimova TG, Zakharenko LP, Bolykhina SA, Dobrotvorsky AK, Morozova OV. Babesia DNA detection in canine blood and Dermacentor reticulatus ticks in southwestern Siberia, Russia. Vector-Borne Zoonotic Dis. 2005;5:285-7.

94. Wei AM, Hu LM, Wu YM, Li HB, Zhang ZQ, Cao WC, et al. Ehrlichia DNA in ticks found in some parts of northeast China. J Prev Med Chin PLA. 2005;22:430-3 (in Chinese).

95. Liu GD, Quan LH. Immuno-fluorescence detection on North Asia Tick Borne Spotted Fever in Dermacentor silvarum. Chin J Zoonoses. 1987;3:20-1 (in Chinese).

96. Mediannikov O, Matsumoto K, Samoylenko I, Drancourt M, Roux V, Rydkina E, et al. Rickettsia raoultii sp. nov., a spotted fever group rickettsia associated with Dermacentor ticks in Europe and Russia. Int J Syst Evol Microbiol. 2008:58:1635-9.
97. Tian ZC, Liu GY, Shen H, Xie JR, Luo J, Tian MY. First report on the occurrence of Rickettsia slovaca and Rickettsia raoultii in Dermacentor silvarum in China. Parasit Vectors. 2012;5:19.

98. Wen J, Jiao D, Wang JH, Yao DH, Liu ZX, Zhao G, et al. Rickettsia raoultii, the predominant Rickettsia found in Dermacentor silvarum ticks in China-Russia border areas. Exp Appl Acarol. 2014;63:679-85.

99. Chen ZG, Chen M, Zhong JP, Bi DZ. Using PCR/ RFLP to detect spotted fever group rickettsia in ticks and rodents collected in Ninghua, Fujian province. Chin J Prev Med. 2002;36:106-8 (in Chinese).

100. Sun CQ, Liu JZ, Huang L, Luobu DZ, Wang YF, Liu ZJ, et al. Molecular prevalence of Anaplasma ovis in Dangxiong county of China Tibet. Prog Vet Med. 2012;33:13-5 (in Chinese).

101. Wang YF, Liu ZJ, Yang JF, Chen Z, Liu JZ, Li YQ, et al. Rickettsia raoultii-like Bacteria in Dermacentor spp. ticks, Tibet, China. Emerg Infect Dis. 2012;18:1532-4.

102. Zhou XR, Liu SK, Chang GS, Wang TX, Ma DX, Dou J, et al. Preliminary investigation on Tularemia in Ali prefecture, the Tibet Autonomous Region of China. Endem Dis Bull. 1993;8:73-7 (in Chinese).

103. Selmi M, Bertolotti L, Tomassone L, Manneli A. Rickettsia slovaca in Dermacentor marginatus and tick-borne lymphadenopathy, Tuscany, Italy. Emerg Infect Dis. 2008;14:817-20.

104. Shpynov S, Parola P, Rudakov N, Samoilenko I, Tankibaev M, Tarasevich I, et al. Detection and identification of spotted fever group rickettsiae in Dermacentor ticks from Russia and central Kazakhstan. Eur J Clin Microbiol Infect Dis. 2001;20:903-5.

105. He JF, Zheng K, Li W, Luo HM, Li LH, Bi DZ, et al. Study on spotted fever group Rickettsiae in Guangdong province. Chin J Epidemiol. 2003;24:700-3. (in Chinese).

106. Ishikura M, Fujita H, Ando S, Matsuura K, Watanabe M, Ishikura M, et al. Phylogenetic analysis of spotted fever group rickettsiae isolated from ticks in Japan. Microbiol Immunol. 2002;46:241-7.

107. Wen B, Cao W, Pan H. Ehrlichiae and ehrlichial diseases in China. Ann N Y Acad Sci. 2003;990:45-53.

108. Yang LP, Zhang TS, Yuan XP, Zi DY. Two strain of Russian spring-summer Encephalitis virus isolated from Boophilus microplus and Hipposideros armiger in Yunan province. Chin J Zoonoses. 1993;9:22-3 (in Chinese).

109. Liu ZL, Ma LH, Gao XS, Cheng XJ, Yang DJ, Wang SY. Study on babesiosis in buffaloes in Hubei province II Experimental infection demonstrated that Rhicephilus haemaphysaloides to be the vector of babesiosis in buffaloes. Acta Vet Zootech Sin. 1987;18:173-8 (in Chinese).

110. Chaudhry D, Garg A, Singh I, Tandon C, Saini R. Rickettsial diseases in Haryana: not an uncommon entity. J Assoc Physicians India. 2009;57:334-7.

111. Liu XM, Zhang GL, Zhao Y, Sun X, Zheng C. Detection of pathogens of main tick-borne diseases in ticks from the desert area of Yuli, Xinjiang Uyghur Autonomous Region, China. Chin J Vector Biol Control. 2012;23:496-8 (in Chinese).

112. Hubálek Z, Halouzka J. West Nile fever-a reemerging mosquito-borne viral disease in Europe. Emerg Infect Dis. 1999;5:643-50.

113. Pan $H$, Chen XR, Ma YH, Sun Y, Yu Q, Tong SD, et al. Ehrlichia canis DNA found in ticks in the south of China. Chin J Zoonoses. 1999;15:3-6 (in Chinese)

114. Estrada-Peňa A, Jongejan F. Ticks feeding on humans: a review of records on human-biting Ixodoidea with special reference to pathogen transmission. Exp Appl Acarol. 1999;23:685-715.

\section{Submit your next manuscript to BioMed Central and take full advantage of:}

- Convenient online submission

- Thorough peer review

- No space constraints or color figure charges

- Immediate publication on acceptance

- Inclusion in PubMed, CAS, Scopus and Google Scholar

- Research which is freely available for redistribution 